\title{
Alkaline phosphatase activity in the subtropical ocean: insights from nutrient, dust and trace metal addition experiments
}

\author{
Claire Mahaffey $^{1}{ }^{*}$, Sarah Reynolds ${ }^{1,2}$, Clare E. Davis ${ }^{1}$ and Maeve C. Lohan ${ }^{3}$ \\ ${ }^{1}$ Department of Earth, Ocean and Ecological Sciences, University of Liverpool, Merseyside, UK \\ ${ }^{2}$ School of Earth and Environmental Sciences, University of Portsmouth, Portsmouth, UK \\ ${ }^{3}$ Marine Chemistry, Biogeochemistry Research Centre, School of Geography, Earth and Environmental Sciences, University of Plymouth, Plymouth, UK
}

\section{Edited by:}

Antonio Tovar-Sánchez, Consejo

Superior de Investigaciones

Cientificas, Spain

Reviewed by:

Sonya Dyhrman, Woods Hole

Oceanographic Institution, USA

Michael William Lomas, Bigelow

Laboratory for Ocean Sciences, USA

\section{${ }^{*}$ Correspondence:}

Claire Mahaffey, Department of

Earth, Ocean and Ecological

Sciences, University of Liverpool,

Nicholson Building, 4 Brownlow

Street, Liverpool, Merseyside L69

3GP, UK

e-mail: mahaffey@liv.ac.uk
Phosphorus is an essential nutrient for all life on earth. In the ocean, the most bioavailable form of phosphorus is inorganic phosphate, but in the extensive subtropical gyres, phosphate concentrations can be chronically low and limit primary productivity and nitrogen fixation. In these regions, organisms produce hydrolytic enzymes, such as alkaline phosphatase (AP), that enable them to utilize the more replete dissolved organic phosphorus (DOP) pool to meet their cellular phosphorus demands. In this study, we synthesized data from 14 published studies and present our own findings from two research cruises (D326 and D361) in the eastern subtropical Atlantic to explore the relationship between AP activity (APA) and nutrients, Saharan dust and trace metals. We found that below a threshold phosphate concentration of $~ 30 \mathrm{nM}$, APA increased with an inverse hyperbolic relationship with phosphate concentration. Meanwhile, DOP concentrations decreased with enhanced APA, indicating utilization of the DOP pool. We found APA rates were significantly higher in the subtropical Atlantic compared to the subtropical Pacific Ocean, even over the same low phosphate concentration range $(0-50 \mathrm{nM})$. While the phosphate concentration may have a first order control on the APA rates, we speculate that other factors influence this basin scale contrast. Using bioassay experiments, we show that the addition of Saharan dust and zinc significantly increased the rate of APA. To our knowledge, our results are the first direct field-based evidence that APA is limited by zinc in the subtropical ocean. Further work is required to explore the relationship between trace metals such as iron and zinc, which are co-factors of phosphohydrolytic enzymes, specifically PhoX and PhoA, respectively, and APA in the ocean.

Keywords: subtropical North Atlantic, alkaline phosphatase, iron, phosphate limitation, zinc

\section{INTRODUCTION}

Phosphorus is an essential macronutrient for all life on earth due to its role in key cellular components such as genetic biomolecules (DNA and RNA), energy transfer molecules (ATP) and cell structure (phospholipids) (Karl and Björkman, 2002). The inorganic form, phosphate, is the most biologically available form of phosphorus in the ocean but its concentration can be chronically low in tropical and subtropical ocean regions (Wu et al., 2000; Cavender-Bares et al., 2001). In contrast, the concentration of dissolved organic phosphorus (DOP) can be 5-10 times higher than phosphate (Mather et al., 2008). DOP is a complex array of molecules consisting of phosphomonesters, phosphodiesters, phosphonates and polyphosphates (Kolowith et al., 2001) although the variability in the contribution of each of these components to DOP is currently unknown, mostly due to the technical difficulty in analysing the different components of DOP (Karl and Yanagi, 1997).
Phytoplankton can assimilate phosphate directly via a high affinity uptake pathway, whereas DOP assimilation requires enzyme-mediated hydrolysis to cleave the phosphate molecule from the organic moiety prior to assimilation. Thus, phytoplankton have a strong metabolic preference for the assimilation of phosphate over DOP to meet their cellular phosphorus demands. However, when phosphate is in short supply, many marine organisms, including the marine filamentous diazotroph, Trichodesmium (Sohm et al., 2008; Orcutt et al., 2013), cyanobacteria such as Synechococcus (Tetu et al., 2009) and Prochlorococcus (Kathuria and Martiny, 2011), some species of dinoflagellate (Dyhrman and Palenik, 1999; Lin et al., 2012), coccolithophores (Jakuba et al., 2008), diatoms (Dyhrman and Ruttenberg, 2006) and bacteria (Huang and Hong, 1999) are known to synthesize hydrolytic enzymes in order to access the DOP pool. Since the late 1980s, studies on phosphohydrolytic enzymes have largely focused on the activity of alkaline phosphatase (AP; Sebastián et al., 2004a,b; Sohm and Capone, 2006; Mather et al., 2008; 
Sohm et al., 2008; Duhamel et al., 2010, 2011; Lomas et al., 2010; Orchard et al., 2010; Suzumura et al., 2012; McLaughlin et al., 2013; Lin et al., 2013; Sato et al., 2013; Wurl et al., 2013; Martin et al., 2014; Reynolds et al., 2014), a group of metalloenzymes that hydrolyse phosphomonoester bonds (Cembella et al., 1984a,b; Hoppe, 2003). As phosphate esters account for up to $70 \%$ of the DOP pool (Karl and Yanagi, 1997; Kolowith et al., 2001; Karl and Björkman, 2002), AP plays a significant role in the cycling and metabolism of phosphorus in the ocean.

Alkaline phosphatase activity (APA) is induced at low phosphate concentrations and regulated by the balance between internal cellular phosphate stores and the supply of phosphate (Cembella et al., 1984a,b; Dyhrman and Ruttenberg, 2006). Studies from a range of marine environments indicate thresholds in phosphate concentration, below which APA is induced. For example, the rate of APA is reported to increase when the concentration of phosphate is less than $10 \mathrm{nM}$ in the Sargasso Sea (Lomas et al., 2010), $\sim 20 \mathrm{nM}$ in the subtropical Pacific (Suzumura et al., 2012) and $\sim 100 \mathrm{nM}$ in the northwest African upwelling region (Sebastián et al., 2004b). These "tipping points" or thresholds may provide valuable information on the phosphate concentration considered to limit or stress the extant phytoplankton community in the open ocean. In addition to this inducible behavior, relatively high rates of APA have been measured in phosphate-replete systems (Sebastián et al., 2004a,b; Dyhrman and Ruttenberg, 2006; Sato et al., 2013), demonstrating the constitutive behavior of AP, which may be indicative of bacterial regeneration of organic phosphorus or demand for easily accessible carbon (Nausch and Nausch, 2004; Neddermann and Nausch, 2004; Luo et al., 2011). The combination of inducible and constitutive behavior of AP means that its relationship with phosphate may be more complex when considered across a spectrum of marine environments, even when considering only the open ocean and excluding coastal regions.

Quantifying the rate of APA involves incubating seawater samples (either filtered or unfiltered) with a synthetic substrate, e.g., 4-methylumbelliferyl-phosphate (MUF-P) or 6,8-difluoro4-methylumbelliferyl phosphate (DiFMUP), that upon hydrolysis of the phosphomonoester bond, releases a soluble fluorescent compound, in this case, methylumbelliferone (Perry, 1972; Ammerman, 1993; Hoppe, 2003). Another technique, called enzyme labeled fluorescence (ELF-97, Dyhrman and Palenik, 1997; Hynes et al., 2009), allows the phosphorus status of individual cells to be assessed through use of a substrate that precipitates an insoluble green product at the site of hydrolysis which is commonly located in the periplasm (Wanner, 1996), but APA rates cannot be quantified using this method. More recently, the presence and expression of the genes encoding for AP, specifically phoA, phoX, and phoD, have been studied in key cyanobacteria including Prochlorococcus (Scanlan et al., 2009; Kathuria and Martiny, 2011; Reistetter et al., 2013), Synechococcus (Scanlan et al., 2009; Tetu et al., 2009), Trichodesmium (Orchard et al., 2009) and diatoms and other eukaryotes (Dyhrman et al., 2012; Lin et al., 2013), providing valuable insight into the distribution and regulation of this enzyme group.

In the subtropical North Atlantic, surface ocean phosphate concentrations are persistently low (Cavender-Bares et al., 2001;
Mather et al., 2008; Sohm et al., 2008; Lomas et al., 2010; Orchard et al., 2010). Of the $450 \mathrm{Tg}$ of dust delivered to the ocean per year, $43 \%$ is deposited on the surface waters of the subtropical North Atlantic alone, resulting in elevated surface ocean iron concentrations (0.2-1.2 nM; Bergquist and Boyle, 2006; Moore et al., 2009; Rijkenberg et al., 2012; Schlosser et al., 2014) relative to other ocean basins (typically $<0.4 \mathrm{nM}$, Boyle et al., 2005; Brown et al., 2005; Blain et al., 2008). Nitrogen fixation is co-limited by iron and phosphate (Mills et al., 2004) and thus, while elevated iron from dust deposition stimulates nitrogen fixation (Mills et al., 2004; Moore et al., 2009; Langlois et al., 2012), phosphate is drawn down to chronically low levels. Bioassay experiments have shown that phosphate limits both nitrogen fixation (Mills et al., 2004) and primary productivity (Moore et al., 2008) in the subtropical Atlantic.

To meet their phosphorus demands in the phosphate-deplete subtropical North Atlantic, phytoplankton and nitrogen fixing organisms (Sohm et al., 2008; Orchard et al., 2010; McLaughlin et al., 2013; Lin et al., 2013; Orcutt et al., 2013) utilize the labile and semi-labile components of the DOP pool. The drawdown of DOP is suggested by the lower DOP concentration and higher APA activity in the phosphate-deplete subtropical North Atlantic compared to the phosphate-replete subtropical South Atlantic where DOP concentrations are elevated and APA almost immeasurable (Mather et al., 2008). There is also a zonal contrast, with higher APA in the western subtropical Atlantic than the eastern subtropical Atlantic (Lomas et al., 2010; Wurl et al., 2013; Reynolds et al., 2014), suggesting that phosphate limitation is more prevalent in the western subtropical Atlantic. These northsouth and east-west basin scale contrasts in phosphorus dynamics are partially constrained by the spatial extent of wet and dry dust deposition (Moore et al., 2006; Schlosser et al., 2014) and hence magnitude and distribution of nitrogen fixation, as well as physical transfer of nutrients via nutrient streams (Williams et al., 2011). However, APA may also be co-limited by trace metals.

The potential for iron to limit nitrogen fixation is due to iron being a co-factor of the enzyme responsible for nitrogen fixation, nitrogenase. In a similar manner, AP is a metalloenzyme. The AP, PhoA, requires both zinc and magnesium (Coleman, 1992). Both culture studies (Cox and Saito, 2013) and ship based observations (Shaked et al., 2006; Jakuba et al., 2008) demonstrate the potential for co-limitation of phosphorus metabolism by zinc, but direct studies, especially in low phosphate regions, are scarce (Jakuba et al., 2008). Recently, the AP PhoX, in the bacteria Pseudomonas fluorescens, has been found to contain iron (Yong et al., 2014). If the iron content of PhoX in P. fluorescens is representative of PhoX in other organisms, then this raises the possibility that iron may directly impact the ability of organisms to access labile fractions of DOP via AP in the ocean (Moore, 2014; Yong et al., 2014). Thus, while the impact of dust deposition on iron biogeochemistry (Sarthou et al., 2003; Rijkenberg et al., 2008, 2012; Mahowald et al., 2009; Baker et al., 2013; Ussher et al., 2013) and nitrogen fixation (Mills et al., 2004; Moore et al., 2009; Langlois et al., 2012) has been well studied in the subtropical Atlantic, the relationship between dust deposition, trace metals and phosphorus biogeochemistry is still poorly understood. 
In this study, we synthesized data collated from 14 studies to explore the relationship between phosphate, DOP and rates of APA across the subtropical Atlantic and Pacific Oceans. In addition, we present new observations from a series of in-situ and bioassay experiments designed to investigate the impact of dust, iron, nutrients and zinc on APA in the subtropical eastern Atlantic Ocean.

\section{MATERIALS AND METHODS}

\section{SYNTHESIS OF DATA ON PHOSPHATE CONCENTRATION AND APA}

Data on the phosphate concentration, rates of APA and chlorophyll a concentration (or chlorophyll $a$ normalized APA) were collated from 14 studies (Table 1). The database includes 807 paired data points for phosphate and APA, 486 paired data points for phosphate and chlorophyll $a$ normalized APA and 475 paired data points for DOP and APA between 0 and $300 \mathrm{~m}$ in the Atlantic and Pacific Oceans (Table 1). Zero values were excluded from the data set. Data was obtained from tables in the original manuscript or directly from the author. Data was grouped by phosphate into $5 \mathrm{nM}$ bins starting from 0 to $5 \mathrm{nM}$ in order to estimate the mean \pm standard error (SE) rate of APA and variability at low phosphate concentrations $(<200 \mathrm{nM})$. To estimate the phosphate concentration below which the rate of APA increases significantly (herein, the threshold phosphate concentration), we compared the APA rate in each $5 \mathrm{nM}$ phosphate bin where phosphate was $<100 \mathrm{nM}$ with the APA rate between 100 and $200 \mathrm{nM}$ using a $t$-test and identified the threshold phosphate concentration as the highest phosphate concentration when $p<0.05$.

Studies reporting rates of APA are often difficult to compare due to the use of different substrate concentrations and different substrates (Duhamel et al., 2010). In this study, we have included data resulting from the use of both a high single substrate concentration $(10-20 \mu \mathrm{M}$ MUF-P) and a range of substrate concentrations $(50-1000 \mathrm{nM})$ because a recent study found that the two methods can yield consistent maximum rates of enzyme activity $\left(\mathrm{V}_{\max }\right)$ in open ocean environments (Suzumura et al., 2012). Two substrates have been used in studies included here, specifically 4-methylumbelliferyl phosphate (MUF-P) was used in 10 studies and 6,8-difluoro-4methylumbelliferyl phosphate (DiFMUP) was used in 3 studies (Table 1). It has been suggested that DiFMUP is less sensitive to changes in $\mathrm{pH}$ than MUF-P and also that the different substrates are accessible to different enzymes. We statistically compared the rates of APA produced using two different substrates to quantitatively assess the impact of substrate choice on the rate of APA using $t$-tests (Supplementary Table 1).

\section{FIELD CAMPAIGNS}

Sampling was conducted onboard the RRS Discovery during two research cruises in 2008 (D326: 5th January to 5th February 2008, SOLAS) and 2011 (D361: 7th February to 19th March 2011, GA06 GEOTRACES) in the eastern subtropical Atlantic (Figure 1, Table 2). Methods used to collect and analyse seawater samples for dissolved iron, aluminum and chlorophyll $a$ are described by Rijkenberg et al. (2012) for D326 and Schlosser et al. (2014) for D361. Whole water rates of nitrogen fixation were determined using the ${ }^{15} \mathrm{~N}_{2}$ technique, involving the addition of $4 \mathrm{ml}$ of ${ }^{15} \mathrm{~N}_{2}$ gas (99\%, Cambridge) to $4 \mathrm{~L}$ of unfiltered seawater and determination of the ${ }^{15} \mathrm{~N}$ content of particulate nitrogen (see methods in Schlosser et al., 2014). Nanomolar concentrations of nitrate and phosphate were determined using standard colorimetric methods using segmented flow analysis coupled to a 2 m liquid waveguide (Patey et al., 2008). Seawater for nutrient and rate measurements was collected using 20 L Niskin bottles attached to a stainless steel

\section{Table 1 | Summary of location, range in phosphate concentration (nM) and rates of alkaline phosphatase activity (APA, $n M d^{-1}$ ) for published studies used in the data synthesis. The substrate (and supplier when reported) used in the study, 4-methylumberlliferyl phosphate (MUF-P), 4-methylumbelliferyl phosphate (MUP) or 6,8-difluoro-4-methylumbelliferyl phosphate (DiFMUP) are noted.}

\begin{tabular}{|c|c|c|c|c|}
\hline Study region & Substrate (supplier) & $\begin{array}{c}\text { Phosphate concentration } \\
\text { range ( } \mathrm{nM})\end{array}$ & $\begin{array}{c}\text { APA } \\
\left(n \mathbf{M ~ d}^{-1}\right)\end{array}$ & Reference \\
\hline Sargasso Sea & DiFMUP (Invitrogen) & $0.5-10.6$ & $19-45$ & Orchard et al., 2010 \\
\hline Atlantic Meridional Transect & MUF-P (Sigma Aldrich) & $5-430$ & $0.9-41$ & Mather et al., 2008 \\
\hline (Sub)-tropical North Atlantic & MUF-P & $25-59$ & $6-184$ & Sohm et al., 2008 \\
\hline (Sub)-tropical North Atlantic & MUF-P & $14-71$ & $4-31$ & Sohm and Capone, 2006 \\
\hline Bermuda Atlantic Time Series & DiFMUP (Invitrogen) & $1-159$ & $0.05-329$ & Lomas et al., 2010 \\
\hline (Sub)-tropical North Atlantic & MUF-P & $5-72$ & $5-148$ & Wurl et al., 2013 \\
\hline Sargasso Sea & MUF-P (2012 data only) & $1-692$ & $0.01-116$ & Martin et al., 2014 \\
\hline (Sub)-tropical Northeast Atlantic & MUF-P (Sigma Aldrich) & $6-926$ & $0.1-122$ & Reynolds et al., 2014 \\
\hline (Sub)-tropical Northeast Atlantic & MUF-P (Sigma Aldrich) & $3-98$ & $0.2-28$ & This study \\
\hline $\begin{array}{l}\text { Hawaii Ocean Time series, subtropical North } \\
\text { Pacific }\end{array}$ & DiFMUP (Molecular Probes) & $13-59$ & $9-31$ & Duhamel et al., 2010 \\
\hline North and South subtropical Pacific & MUF-P(Sigma Aldrich) & $12-117$ & $0.3-9$ & Duhamel et al., 2011 \\
\hline subtropical Northwestern Pacific & MUF-P(Sigma Aldrich) & $8-116$ & $5-18$ & Suzumura et al., 2012 \\
\hline Subtropical North Pacific & MUF-P & $31-71$ & $0.5-19$ & Sohm et al., 2008 \\
\hline North and South subtropical Pacific & MUP (Invitrogen) & $3-141$ & $2-90$ & Sato et al., 2013 \\
\hline
\end{tabular}




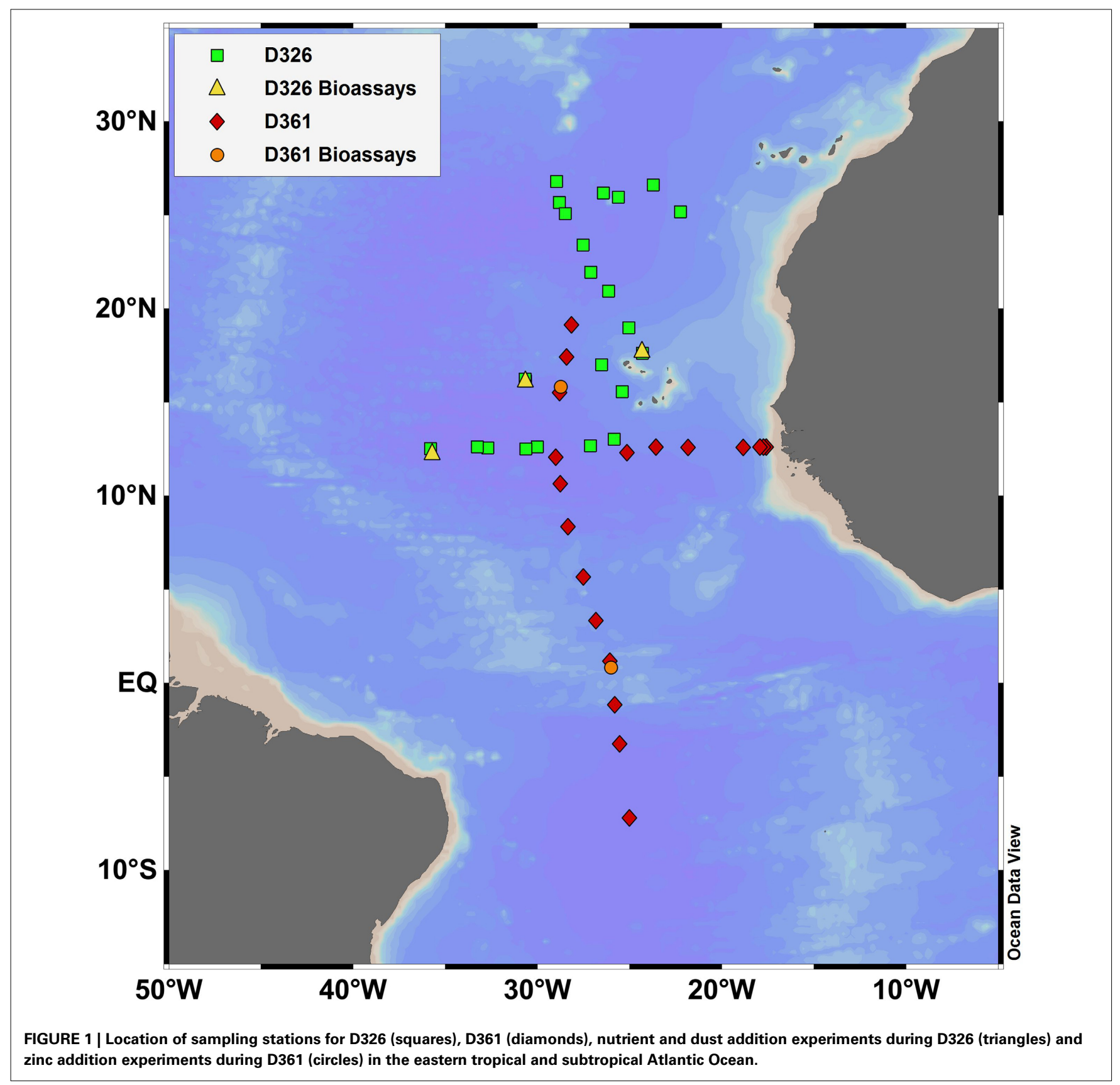

rosette. Seawater used for nutrient, dust, and zinc addition experiments was collected using the trace metal clean towed fish at $\sim 3 \mathrm{~m}$ depth as previously described (Rijkenberg et al., 2012; Schlosser et al., 2014). Sampling and nutrient additions were performed under strict trace metal clean protocols in an over-pressurized clean air container onboard the ship.

\section{Alkaline phosphatase activity}

Whole water rates of APA were measured during D326 and D361 using the fluorimetric substrate MUF-P (Ammerman, 1993) following protocols reported in Sohm et al. (2008) and Reynolds et al. (2014). Briefly, $250 \mathrm{ml}$ of unfiltered seawater was incubated in a polycarbonate bottle after the addition of MUF-P substrate at a concentration of $200 \mathrm{nM}$, or at a range of concentrations between 200 and $1000 \mathrm{nM}$. Bottles were placed in on-deck incubators, which were cooled with surface seawater and adjusted to in-situ light intensity. Fluorescence was measured at the start of the incubation and approximately every $2 \mathrm{~h}$ for up to $24 \mathrm{~h}$ using a Turner $10 \mathrm{AU}$ field fluorometer fitted with a long wavelength oil lab filter kit (10-302R).

\section{Nutrient and dust addition experiments (D326)}

Nutrient and dust addition experiments were conducted at 4 stations in the eastern subtropical gyre during D326 (Figure 1) with APA measurements made on 3 experiments (herein B2-B4, Table 3). Unfiltered seawater was collected in $20 \mathrm{~L}$ carboys from 


\begin{tabular}{|c|c|c|}
\hline Parameter & D326 & D361 \\
\hline Dates & $\begin{array}{l}\text { 5th January to 5th } \\
\text { February } 2008\end{array}$ & $\begin{array}{l}\text { 7th February to 19th } \\
\text { March } 2011\end{array}$ \\
\hline $\mathrm{SST}\left({ }^{\circ} \mathrm{C}\right)$ & $21.05-25.01$ & $22.93-28.69$ \\
\hline Chlorophyll a ( $\mu \mathrm{g} \mathrm{L}^{-1}$ ) & $0.13-0.32$ & $0.05-0.33$ \\
\hline Phosphate (nM) & $3-98$ & $12-99$ \\
\hline Nitrate (nM) & $6-70$ & $1-49$ \\
\hline Iron (nM) & $0.07-0.37$ & $0.02-0.96$ \\
\hline Aluminum (nM) & $10-47$ & $10-64$ \\
\hline DOP (nM) & $75-186$ & 71-192 \\
\hline APA $\left(n M d^{-1}\right)$ & $0.2-28$ & $0.7-20$ \\
\hline APA (nmol $\mu \mathrm{g} \mathrm{chl} \mathrm{d}^{-1}$ ) & $1-101$ & $1-144$ \\
\hline $\begin{array}{l}\text { Surface nitrogen fixation } \\
\text { rate }\left(n \mathrm{nd} \mathrm{d}^{-1}\right)\end{array}$ & $0.06-25$ & $0.6-5.8$ \\
\hline
\end{tabular}

the towed fish. Initial concentrations and rate measurements were made on unfiltered seawater before the addition of nutrients. Nutrient addition experiments involved the single addition of nitrogenous nutrients $(1 \mu \mathrm{M}$ of ammonium plus $1 \mu \mathrm{M}$ of nitrate), phosphate $(0.2 \mu \mathrm{M})$ or iron $(2 \mathrm{nM}$ of iron in dilute hydrochloric acid) or a combination of two or three nutrients. In parallel, $2 \mathrm{mg}$ per L of dust (D1) or $2 \mathrm{mg}$ per L of dust treated with sulphuric acid to simulate atmospheric processing (D2) was added to incubation bottles (Xylouri, 2009). A control was conducted in parallel to quantify the influence of the added nutrients or dust on the rates of APA and biomass relative to containment. Dust dissolution experiments conducted in parallel found that the addition of D1 and D2 would result in a release of $<0.2 \mathrm{nM}$ and $<1 \mathrm{nM}$ of dissolved iron (Xylouri, 2009). Bottles were incubated for $48 \mathrm{~h}\left(\mathrm{~T}_{48 \mathrm{~h}}\right)$ at $20 \%$ surface light and cooled with surface seawater. At $\mathrm{T}_{48 \mathrm{~h}}$, a suite of samples were taken for analysis of chlorophyll $a$, Fv:Fm ratio, rates of nitrogen fixation and rates of APA (sampled from only one triplicate incubation bottle). Here, we report the volumetric and chlorophyll $a$ normalized rates of APA only. All incubations were conducted in triplicate. However, the rates of APA were determined using seawater from one replicate carboy only, meaning that statistical analysis between the control and treatments and between treatments were not possible. Here, we focus on the relative magnitude of the response and do not attempt to make any statistical comparison between treatments within an experiment. However, the change in the rate of APA after the addition of nutrients and trace metals was consistent between experiments (see Section Nutrient, iron, and dust bioassays), implying that our results were reproducible.

\section{Zinc addition experiments (D361)}

To investigate the potential for zinc to limit the rate of APA, zinc addition experiments were performed at $1^{\circ} \mathrm{N}(\mathrm{Zn} 1)$ and at $\sim 16^{\circ} \mathrm{N}(\mathrm{Zn} 2)$ in the eastern tropical and subtropical Atlantic during D361. Unfiltered seawater was collected from the towed fish into $10 \mathrm{~L}$ carboys and incubated for $48 \mathrm{~h}\left(\mathrm{~T}_{48 \mathrm{~h}}\right)$ at $20 \%$ surface
Table 3 | Date, location and initial concentrations ( \pm standard deviation) of inorganic and organic nutrients (nM), trace metals (nM), surface ocean rates of alkaline phosphatase activity (APA, $n M d^{-1}$ ) and nitrogen fixation $\left(n M d^{-1}\right)$ at the start $\left(T_{0}\right)$ of bioassays conducted in the eastern subtropical Atlantic during D326 (Spring 2008).

\begin{tabular}{llll}
\hline Parameter & B2 & B3 & B4 \\
\hline Date & 15 th January & 21 st January & 25 th January \\
& 2008 & 2008 & 2008 \\
Location & $17.7^{\circ} \mathrm{N}, 24.3^{\circ} \mathrm{W}$ & $12.3^{\circ} \mathrm{N}, 35.8^{\circ} \mathrm{W}$ & $16.1^{\circ} \mathrm{N}, 30.6^{\circ} \mathrm{W}$ \\
$\mathrm{SST}\left({ }^{\circ} \mathrm{C}\right)$ & 22.33 & 24.89 & 23.45 \\
Chlorophyll a ( $\mathrm{gg}$ & 0.31 & 0.19 & 0.13 \\
$\mathrm{~L}^{-1}$ ) & & & \\
Phosphate (nM) & $85 \pm 1$ & $14 \pm 1$ & $12 \pm 2$ \\
Nitrate (nM) & $19 \pm 2$ & $12 \pm 1$ & $6 \pm 1$ \\
$\mathrm{~N}: \mathrm{P}$ & $\sim 0.2$ & $\sim 0.9$ & $\sim 0.5$ \\
Iron (nM) & $0.09 \pm 0.03$ & $0.23 \pm 0.01$ & $0.21 \pm 0.002$ \\
Aluminum (nM) & $10 \pm 2$ & $27 \pm 1$ & $26 \pm 2$ \\
DOP (nM) & 124 & 147 & 152 \\
APA (nM d ${ }^{-1}$ ) & 3.48 & 8.48 & 14.01 \\
Surface nitrogen & $0.1 \pm 0.1$ & $3.0 \pm 0.3$ & $25 \pm 0.5$ \\
fixation rate & & & \\
(nM d ${ }^{-1}$ ) & & & \\
\hline
\end{tabular}

light after the addition of 1.3 or $1.9 \mathrm{nM}$ of zinc chloride in $\mathrm{Zn} 1$ and $\mathrm{Zn} 2$, respectively. Control incubations (no zinc addition) were conducted in parallel. All incubations were performed in triplicate. At $\mathrm{T}_{48 \mathrm{~h}}$, a suite of samples were taken for analysis of phosphate, chlorophyll $a$, zinc and rates of APA. The concentration of zinc was determined using flow injection with fluorimetric detection as previously described (Wyatt et al., 2014). The rate of APA was determined in triplicate using methods described above except that a single substrate addition of $100 \mathrm{nM}$ MUF-P was used. The rates of APA were measured within $8 \mathrm{~h}$ of adding the MUF-P substrate. Pairwise comparisons between controls and treatments were performed using a $t$-test and significance is reported where $p<0.05$.

\section{RESULTS}

\section{SYNTHESIS OF DATA ON PHOSPHATE CONCENTRATION AND APA}

Laboratory and field studies show that the rate of APA increases with decreasing phosphate concentration, suggesting that APA is regulated by the supply of phosphate (Cembella et al., 1984a,b; Mather et al., 2008; Lomas et al., 2010; Duhamel et al., 2011; Suzumura et al., 2012). We collated data from 14 studies (Table 1) with phosphate ranging from 0.5 to $926 \mathrm{nM}$ and the rate of APA ranging from 0.01 to $329 \mathrm{nM} \mathrm{d}^{-1}$ for the entire data set (Supplementary Figure 1). Our analysis supports the general observation of an inverse hyperbolic relationship between the concentration of phosphate and rate of APA (Supplementary Figure 1). When grouped into $5 \mathrm{nM}$ phosphate bins, the mean $( \pm \mathrm{SE})$ rate of APA in the lowest phosphate bins of $0-5 \mathrm{nM}$ and $5-10 \mathrm{nM}$ were $53 \pm 5 \mathrm{nM} \mathrm{d}^{-1}(n=121$, from 0.5 to $\left.329 \mathrm{nM} \mathrm{d}^{-1}\right)$ and $51 \pm 3 \mathrm{nM} \mathrm{d}^{-1}(n=154$, from 0.8 to $249 \mathrm{nM}$ $\mathrm{d}^{-1}$, Figure 2A). A 2-3-fold increase in phosphate (10-15 nM) 

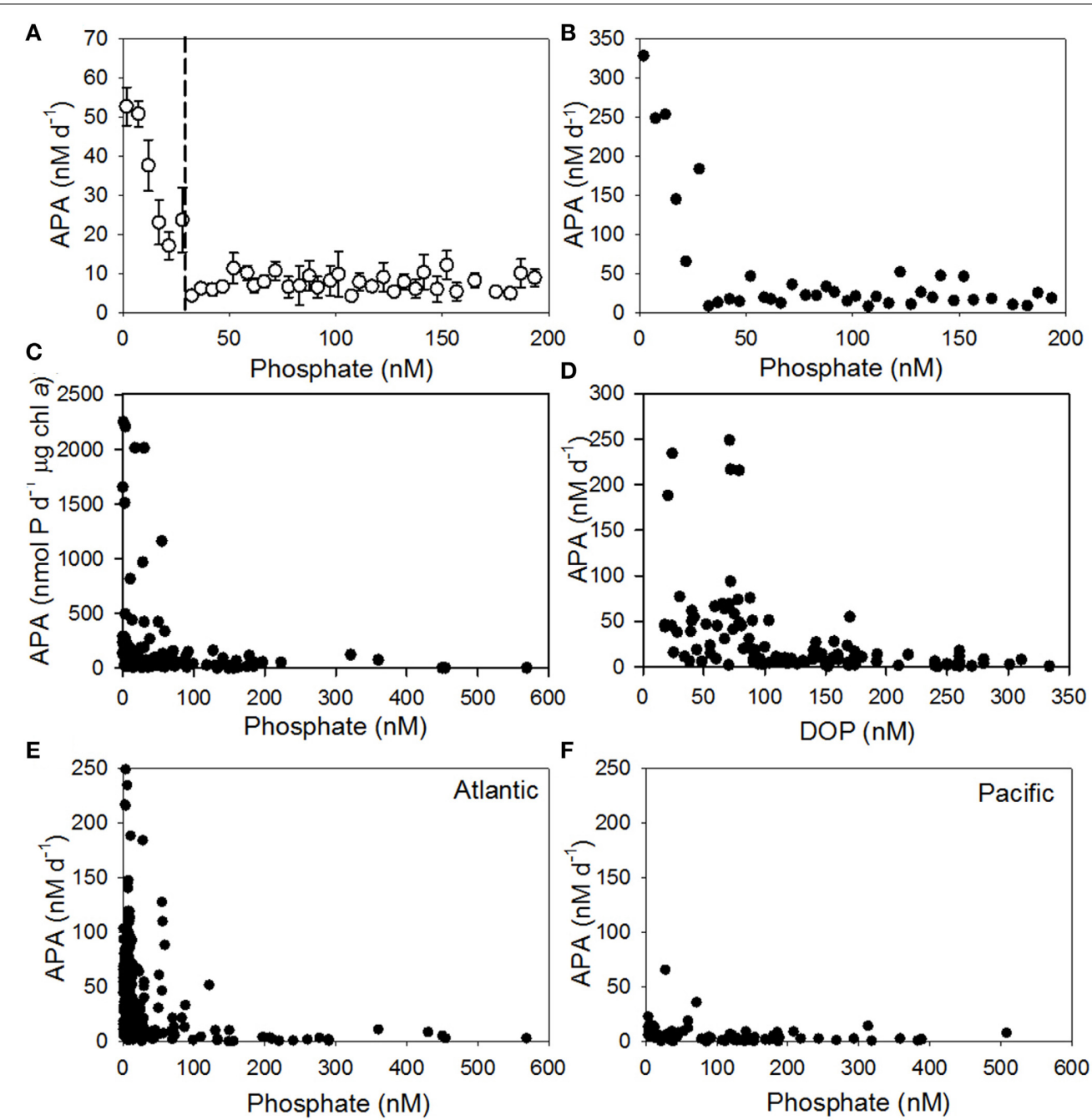

FIGURE 2 | Relationship between (A) mean volumetric rates of alkaline phosphatase activity (APA) \pm standard error (SE) relative to phosphate concentration ( $\mathrm{nM}$ ) from 14 studies, grouped into bins of $5 \mathrm{nM}$ starting at 0-5 $\mathbf{~ M M}$. Dashed line represents the threshold concentration at $\sim 30 \mathrm{nM}$ (B) maximum volumetric rate of APA $\left(\mathrm{nM} \mathrm{d}^{-1}\right)$ relative to phosphate concentration ( $\mathrm{nM}$ ) grouped into bins of $5 \mathrm{nM}$ starting at $0-5 \mathrm{nM}$ (C) chlorophyll a normalized rate of APA ( $\mathrm{nmol} \mathrm{d}{ }^{-1} \mu \mathrm{g} \mathrm{chl} \mathrm{a)} \mathrm{for} \mathrm{surface} \mathrm{waters} \mathrm{only}(0-20 \mathrm{~m}$ )

reduced the mean rate of APA to $38 \pm 7 \mathrm{nM} \mathrm{d}^{-1}(n=72$, ranging from 2 to $254 \mathrm{nM} \mathrm{d}^{-1}$ ) and a 3-4-fold increase in phosphate (15-20 nM) more than halved the rate of APA to $23 \pm 6 \mathrm{nM}$ $\mathrm{d}^{-1}$ ( $n=33$, from 0.9 to $145 \mathrm{nM} \mathrm{d}^{-1}$ ), highlighting the sensitivity of AP to increasing phosphate concentrations even at nanomolar phosphate concentrations. From our analysis, the rate of APA in the 25-30 nM phosphate bin was significantly higher than the rate of APA in the $100-200 \mathrm{nM}$ phosphate bin ( $p=$ 0.042 ). This implies that the threshold phosphate concentration was $\sim 30 \mathrm{nM}$ (Figure 2A, dashed line). Below this concentration, the mean rate (Figure $2 \mathbf{A}$ ) and maximum rate (Figure $2 \mathbf{B}$ ) of APA increased above a background APA rate observed at phosphate concentrations greater than $50 \mathrm{nM}$. The relationship between phosphate and APA is the same when the volumetric rate of APA is normalized to chlorophyll $a$ (Figure 2C). relative to phosphate concentration $(n M)$ and $(D)$ rates of APA $\left(n M d^{-1}\right)$ relative to the concentration of dissolved organic phosphorus (DOP, nM) for surface waters only $(0-20 \mathrm{~m})$ and $(\mathbf{E})$ rate of APA $\left(\mathrm{nM} \mathrm{d}^{-1}\right)$ relative to phosphate concentration $(\mathrm{nM})$ for surface waters only $(0-20 \mathrm{~m})$ for data collected from the Atlantic Ocean and $(\mathbf{F})$ rate of APA $\left(\mathrm{nM} \mathrm{d}^{-1}\right)$ relative to phosphate concentration $(\mathrm{nM})$ for surface waters only $(0-20 \mathrm{~m})$ for data collected from the Pacific Ocean. See Table 1 for details of studies included in this Figure.

The increase in the rate of APA at low phosphate concentrations clearly has an impact on the concentration of DOP, which decreases as APA increases (Figure 2D). The mean rate of APA $( \pm \mathrm{SE})$ when DOP $<100 \mathrm{nM}$ is $52 \pm 8 \mathrm{nM} \mathrm{d}^{-1}(n=$ 54) compared to $7 \pm 1 \mathrm{nM} \mathrm{d}^{-1}(n=120)$ when DOP is $>$ $100 \mathrm{nM}$.

We compared the rates of APA resulting from the use of two substrates, MUF-P and DiFMUP (Supplementary Table 1). When the rate of APA is compared for the entire data set, the Atlantic ocean only or when phosphate is $<100 \mathrm{nM}$, the rate of APA generated using DiFMUP is significantly higher $(p<0.001)$ than the rate of APA generated using MUF-P (Supplementary Table 1). However, due to the location of the studies that used DiFMUP, the phosphate concentration was also significantly lower $(p<0.001)$ in studies that used DiFMUP compared to those that used MUF-P 
(Supplementary Table 1). Comparison of the rate of APA using data collected in the Pacific Ocean only showed that there was no significant difference in rates of APA generated using DiFMUP or MUF-P, despite phosphate being significantly lower $(p=0.009)$ in studies using DiFMUP. In light of the sensitivity of APA rates to the concentration of phosphate and the significant differences in the phosphate concentration between studies that used DiFMUP versus those that used MUF-P, we cannot verify if the use of different substrates has an impact on the resulting rates of APA and thus, we consider the patterns shown in our data synthesis to be a reflection of the response of APA to environmental conditions and not the use of different substrates. Further assays using different substrates in the same region would be required to investigate the influence of substrate on the accuracy of rates of APA.

We compared the surface ocean $(0-20 \mathrm{~m})$ phosphate and rates of APA between the subtropical Atlantic and subtropical Pacific (Figures 2E,F, respectively). The mean ( $\pm \mathrm{SE}$ ) phosphate concentration in the subtropical Atlantic $(45 \pm 5 \mathrm{nM}, n=299)$ was half that observed in the subtropical Pacific ( $108 \pm 11 \mathrm{nM}, n=88)$. The mean $( \pm \mathrm{SE})$ DOP concentration was also lower in the subtropical Atlantic $(131 \pm 7 \mathrm{nM}, n=141)$ relative to the subtropical Pacific $(229 \pm 52, n=60)$. The volumetric rate of APA was significantly higher $(p<0.001)$ in the subtropical Atlantic $(39 \pm 2 \mathrm{nM}$ $\mathrm{d}^{-1}$, ranging from 0.4 to $\left.249 \mathrm{nM} \mathrm{d}^{-1}, n=299\right)$ relative to the subtropical Pacific $\left(6 \pm 1 \mathrm{nM} \mathrm{d}^{-1}\right.$, ranging from 0.2 to $90 \mathrm{nM} \mathrm{d}^{-1}$, $n=88$ ). The biomass corrected rate of APA was also significantly higher in the subtropical Atlantic $\left(692 \pm 44 \mathrm{nmol} \mathrm{P} \mathrm{d}^{-1} \mu \mathrm{g}\right.$ chl a) compared to the subtropical Pacific ( $91 \pm 22 \mathrm{nmol} \mathrm{P} \mathrm{d}{ }^{-1} \mu \mathrm{g}$ chl $a, p=<0.001)$, implying that the extant phytoplankton population were more phosphate stressed in the subtropical Atlantic relative to the subtropical Pacific. Overall, the higher mean rate of APA in the subtropical Atlantic relative to the subtropical Pacific, is to a first order, due to the higher phosphate concentration in the subtropical Pacific. However, when the rate of APA is compared over the same relatively low phosphate concentration range $(0-50 \mathrm{nM})$, the mean rate $( \pm \mathrm{SE})$ of APA in the subtropical Atlantic ( $\left.43 \pm 3 \mathrm{nM} \mathrm{d}^{-1}, n=242\right)$ is more than 4-fold higher than in the subtropical Pacific ( $\left.9 \pm 2 \mathrm{nM} \mathrm{d}^{-1}, n=35\right)$, implying other factors are controlling the rate of APA in the subtropical Pacific. A striking feature of the subtropical North Atlantic is that it receives $43 \%$ of global dust deposition, whereas the North and South Pacific Oceans receive only 15 and 6\% respectively (Jickells et al., 2005). To explore this further, we examined the impact of dust on the rate of APA.

\section{IMPACT OF NUTRIENTS, IRON, AND DUST ON APA FROM BIOASSAY EXPERIMENTS \\ Hydrography and characteristics of the subtropical Atlantic}

The eastern subtropical Atlantic, the region of study on both D326 and D361, is a warm, permanently stratified, oligotrophic region (Table 2; Rijkenberg et al., 2012; Reynolds et al., 2014). Surface phosphate concentrations were below $100 \mathrm{nM}$, excluding the northwest African upwelling region, during both field campaigns (Table 2). Surface iron concentrations were highly variable (Table 2) due to a large atmospheric dust event during D326 (Rijkenberg et al., 2012) and wet deposition in the inter-tropical convergence zone (ITCZ) during D361 (Schlosser et al., 2014).

\section{Dust deposition event and APA}

During D326, there was a strong atmospheric dust event between 17th and 19th January 2008 and 25th to 1st January 2008, which resulted a significant increase in the surface concentration of iron (from $0.05 \pm 0.02 \mathrm{nM}$ to $0.15 \pm 0.02 \mathrm{nM}$ ) and phosphate (from 30 $\pm 20 \mathrm{nM}$ to $80 \pm 20 \mathrm{nM}$, Rijkenberg et al., 2012). Volumetric and chlorophyll normalized rates of APA for the entire D326 cruise ranged from $0.2 \mathrm{nM} \mathrm{d}^{-1}$ to $28 \mathrm{nM} \mathrm{d}^{-1}$ and 1 to $101 \mathrm{nmol} \mathrm{P} \mathrm{d}^{-1} \mu \mathrm{g}$ chl $a$ (Tables 1, 2). The rate of APA decreased from $6.1 \pm 2.1 \mathrm{nM}$ $\mathrm{d}^{-1}$ (or $39 \pm 14 \mathrm{nmol} \mathrm{d}^{-1} \mu \mathrm{g}$ chl $a$ ) to $3.9 \pm 0.1 \mathrm{nM} \mathrm{d}^{-1}$ (or $19.2 \pm 0.4 \mathrm{nmol} \mathrm{d}^{-1} \mu \mathrm{g} \mathrm{chl} a$ ) after the dust event. The relationship between dust and APA was explored further in a series of bioassays.

\section{Nutrient, iron, and dust bioassays}

The rate of APA was measured during nutrient, trace metal and dust addition experiments conducted during D326. B2 was performed using seawater that was relatively phosphate-replete and iron-deplete with high biomass and low nitrogen fixation rates (Table 3). In contrast, the B3 and B4 were performed using seawater that was relatively phosphate-deplete and iron-replete with low biomass and enhanced rates of nitrogen fixation (Table 3 ).

The rate of APA in the control relative to APA at $T_{0}$ increased $>10$-fold in $\mathrm{B} 2$, remained unchanged in B3 and doubled in B4 after the $48 \mathrm{~h}$ incubation period (Figures 3A,C,E, respectively). The reasons for such a large change in the control in $\mathrm{B} 2$ are unclear, especially as the phosphate concentration at $\mathrm{T}_{0}$ was $\sim 80 \mathrm{nM}$, above the $30 \mathrm{nM}$ threshold previously discussed. Thus, changes in the rates of APA will be compared to the control at $\mathrm{T}_{48 \mathrm{~h}}$ and not the rate of APA at $\mathrm{T}_{0}$. Although there was a large increase in the rate of APA in the control in $\mathrm{B} 2$, a response to the addition of nutrients and dust relative to the control was still noticeable and indeed, a clear pattern emerged in the response to nutrients and dust in all three experiments.

Firstly, the rate of APA decreased after the addition of phosphate alone or in combination with nitrogen and/or iron, demonstrating the repressible behavior of AP with increasing phosphate concentrations (Figures 3A,C,E; Sebastián et al., 2004a,b). The addition of iron alone decreased the rate of APA relative to the control. Secondly, the rate of APA increased only slightly in B2 but by two orders of magnitude in B3 and B4 after the addition of nitrogen alone or with iron, probably because the system was shifted toward phosphate limitation. Lastly, the rate of AP increased 6-fold in B3 (Figure 3C) after the addition of D1 and 6fold in B3 (Figure 3C) and 2-fold in B4 (Figure 3E) after the addition of D2. In B2, the addition of D1 and D2 increased the rate of APA slightly above that observed in the control (Figure 3A). When normalized to the concentration of chlorophyll $a$ at $\mathrm{T}_{48 \mathrm{~h}}$, the same pattern was observed as phosphate (and iron alone) repressed the rate of APA, whilst nitrogen, dust and processed dust enhanced the rate of APA (Figures 3B,D,F).

\section{Impact of zinc on APA}

As zinc is a co-factor of some AP, such as PhoA, we explored the influence of zinc on the rate of APA. SST was $\sim 5^{\circ} \mathrm{C}$ warmer at sampling site of $\mathrm{Zn} 1$ compared to $\mathrm{Zn} 2$ (Table 4). The concentration of phosphate was $>10$-fold higher at the start $\left(\mathrm{T}_{0}\right)$ 

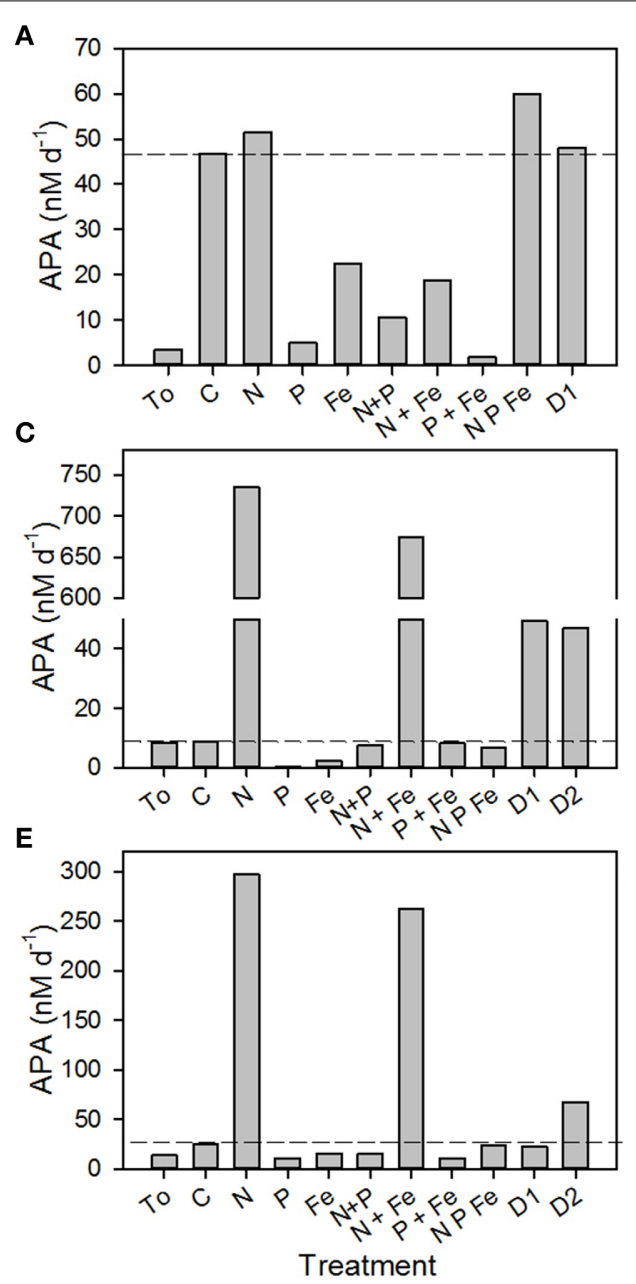

FIGURE 3 | Volumetric rates (nM d $\left.{ }^{-1}, A, C, E\right)$ and chlorophyll a normalized rates ( $\mathrm{nmol} \mathrm{P} \mathrm{d}^{-1} \mu \mathrm{g} \mathrm{chl} \mathrm{a,} \mathrm{B} \mathrm{D,F)} \mathrm{of} \mathrm{alkaline} \mathrm{phosphatase}$ activity (APA) in response to the addition of nitrogen (N $1 \mu \mathrm{M}$ of ammonium plus $1 \mu \mathrm{M}$ of nitrate), phosphate $(\mathrm{P}, 0.2 \mu \mathrm{M})$, iron ( $\mathrm{Fe}, 2 \mathrm{nM}$ of iron in dilute hydrochloric acid), a combination of 2 or 3 nutrients,

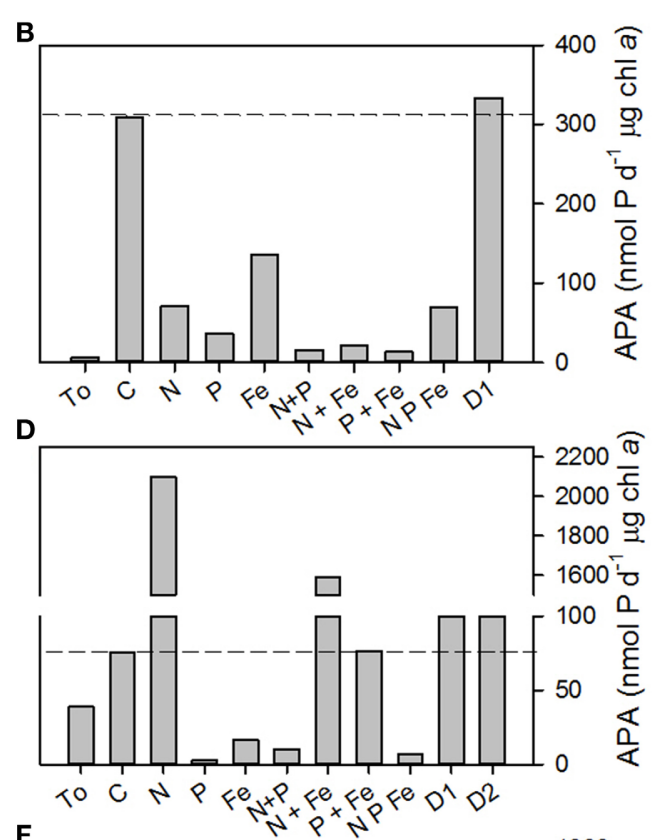

$\mathbf{F}$

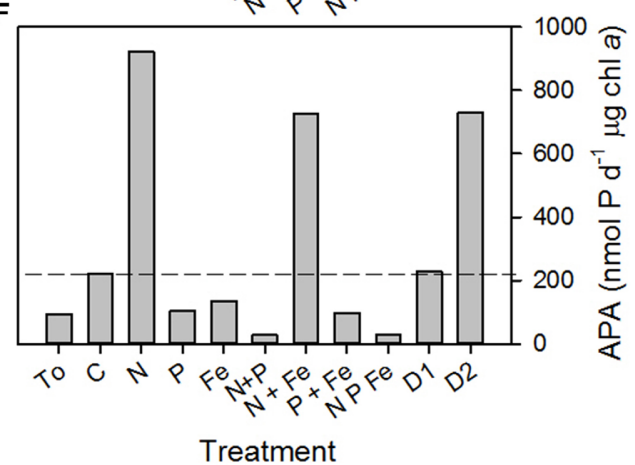

dust (D1) and processed dust (D2) at (A,B) B2, 17.7 $\mathrm{N}, 24.3^{\circ} \mathrm{W},(\mathrm{C}, \mathrm{D}) \mathrm{B} 3$, $12.3^{\circ} \mathrm{N}$ and $35.8^{\circ} \mathrm{W}$ and $(\mathrm{E}, \mathrm{F}) \mathrm{B} 4$ at $16.1^{\circ} \mathrm{N}$ and $30.6^{\circ} \mathrm{W}$. Data presented represents the initial rate of APA $\left(T_{0}\right)$ and the rate of APA after incubation with nutrients for $48 \mathrm{~h}\left(T_{48 \mathrm{~h}}\right)$. Dashed lines represent the rate of APA in the control incubation at $\mathrm{T}_{48 \mathrm{~h}}$. of $\mathrm{Zn} 1(\sim 43 \mathrm{nM})$ compared to $\mathrm{Zn} 2(\sim 3 \mathrm{nM})$ but the DOP and nitrate plus nitrite concentrations were similar (Table 4). The concentration of iron and zinc, and the integrated rates of nitrogen fixation were 2 -fold higher in surface waters in the subtropical North Atlantic ( $\mathrm{Zn} 2)$ compared to close to the equator (Zn1; Table 4).

The rate of APA at $\mathrm{T}_{0}$ of $\mathrm{Zn} 1$ was below our limits of detection $\left(\sim 0.5 \mathrm{nM} \mathrm{d}^{-1}\right)$. After $48 \mathrm{~h}\left(\mathrm{~T}_{48 \mathrm{~h}}\right)$, the volumetric and chlorophyll $a$ normalized rate of APA was measurable in both the control and treatment incubations and were almost 3-fold higher in the treatment relative to the control $(\mathrm{p}=0.045$ and $\mathrm{p}=0.049$, respectively, Figures $4 A, C)$. Between $T_{0}$ and $T_{48 h}$ during $Z n 2$, the volumetric and chlorophyll $a$ normalized rate of APA increased 3 -fold and 6-fold respectively in the control and 6-fold and 8-fold respectively in the treatment (Figures 4B,D). The increase in the rate of APA in the added zinc treatment was significantly higher than observed in the control for both volumetric and chlorophyll a normalized rates $(p<0.001$, Figures $4 \mathrm{~B}, \mathbf{D})$. The concentration of phosphate remained relatively constant throughout $\mathrm{Zn} 1$ but the zinc concentration decreased from $1.66 \pm 0.02 \mathrm{nM}$ to $0.6 \pm$ $0.1 \mathrm{nM}$ by $\mathrm{T}_{48 \mathrm{~h}}$. The phosphate concentration was not measured during $\mathrm{Zn} 2$ but the zinc concentration decreased from $2.1 \pm 0.04$ to $1.7 \pm 0.2 \mathrm{nM}$ by $\mathrm{T}_{48 \mathrm{~h}}$. These experiments demonstrate that the addition of zinc stimulated APA, despite the zinc concentration being almost 2 -fold higher at $\mathrm{Zn} 2$ compared to $\mathrm{Zn} 1$ at $\mathrm{T}_{0}$ (Table 4). However, a zinc concentration of $0.3 \mathrm{nM}$ is considered to be fairly low and therefore we speculate that APA may have been limited by the availability of dissolved zinc in our study area of the tropical and subtropical Northeast Atlantic Ocean.

\section{DISCUSSION}

Results from our data synthesis, in-situ observations and bioassay experiments highlight the sensitivity of APA to the concentration of phosphate. We estimate that the threshold phosphate 


\section{Table 4 | Date, location and initial concentrations ( \pm standard deviation) of inorganic and organic nutrients (nM), trace metals (nM) and rates of alkaline phosphatase activity (APA, $n M d^{-1}$ ) and

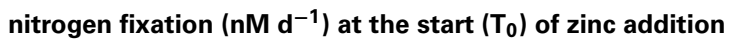 experiments conducted in the eastern subtropical Atlantic during D361 (Spring 2011).}

\begin{tabular}{|c|c|c|}
\hline Parameter & Zn 1 & Zn 2 \\
\hline Date & 1st March 2011 & 13th March 2011 \\
\hline Location & $0.83^{\circ} \mathrm{N}, 25.23^{\circ} \mathrm{W}$ & $15.81^{\circ} \mathrm{N}, 28.73^{\circ} \mathrm{W}$ \\
\hline $\mathrm{SST}\left({ }^{\circ} \mathrm{C}\right)$ & 28.3 & 23.8 \\
\hline Chlorophyll a ( $\left.\mu \mathrm{g} \mathrm{L}^{-1}\right)$ & 0.110 & 0.110 \\
\hline Phosphate (nM) & 43 & 3 \\
\hline Nitrate + nitrite $(\mathrm{nM}) *$ & 13 & 14 \\
\hline Zinc (nM) & $0.16 \pm 0.01$ & $0.30 \pm 0.01$ \\
\hline Iron $(\mathrm{nM})^{*}$ & $0.08 \pm 0.01$ & $0.16 \pm 0.01$ \\
\hline $\mathrm{DOP}(\mathrm{nM}) *$ & $172 \pm 10$ & $158 \pm 8$ \\
\hline APA $\left(n M d^{-1}\right)$ & No measurable activity & $9.0 \pm 0.9$ \\
\hline $\begin{array}{l}\text { Integrated nitrogen fixation } \\
\text { rate }\left(\mu \mathrm{mol} \mathrm{m}^{-2} \mathrm{~d}^{-1}\right)^{* a}\end{array}$ & 88 & 142 \\
\hline
\end{tabular}

*Based on nearest station or FISH data.

${ }^{a}$ From Schlosser et al. (2014).

concentration required to induce APA is $\sim 30 \mathrm{nM}$, below which the rate of APA increases significantly. As the concentration of phosphate decreased from 15 to $20 \mathrm{nM}$ to 0 to $5 \mathrm{nM}$, we observed a $50 \%$ increase in the rate of APA. After a dust deposition event, where the phosphate concentration increased from $\sim 30$ to $80 \mathrm{nM}$ and thus above the $30 \mathrm{nM}$ threshold, we observed a decline in the rate of APA. Bioassay experiments revealed that the addition of phosphate alone or in combination with nitrogen and/or iron repressed APA in bioassay experiments. Collectively, our findings support the use of APA as an indicator for phosphate stress, provides useful constraints on rates of APA relative to the phosphate concentration in open ocean and provides insight into the dynamics of phosphate limitation on a broad basin scale.

The impact of APA on DOP is clearly seen from our data synthesis, where the concentration of DOP decreases at elevated rates of APA, supporting meridional observations from the subtropical Atlantic (Mather et al., 2008). To maintain surface ocean concentrations, DOP must either be regenerated locally (McLaughlin et al., 2013) or be advected in from regions where there is net production of DOP (Lomas et al., 2010; Reynolds et al., 2014), such as the flanks of gyres or adjacent upwelling regions where there is enhanced productivity.

In contrast to our in-situ observations following a dust deposition event, the rate of APA increased after the addition of dust in the bioassay experiments. The addition of dust has been known to increase the rate of nitrogen fixation in bioassays (Mills et al., 2004; Langlois et al., 2012) and increase the abundance and enhance colony formation of nitrogen fixing organisms (Langlois et al., 2012). Enhanced nitrogen fixation would certainly stimulate the rate of APA, especially if the diazotroph community included Trichodesmium, which is known to intensively use AP to access labile DOP compounds to sustain its cellular phosphorus demand (Sohm et al., 2008; Orcutt et al., 2013). However, there was no measurable increase in the rate of nitrogen fixation after the addition of D1 or D2 during these bioassays (Moore, personal communication). Either the rates of nitrogen fixation sustained were sufficient to drawdown phosphate and stimulate APA within the $48 \mathrm{~h}$ incubation period, or other factors induced APA.

The increase in APA may be due to subtle differences in nutrient stocks. We added $2 \mathrm{mg}$ of dust per $\mathrm{L}$ of seawater during the dust addition experiments. Assuming that dust contains $0.1 \%$ phosphorus and $0.12 \%$ nitrogen (Guieu et al., 2002; Mills et al., 2004), we estimate that $65 \mathrm{nmol}$ phosphorus and $170 \mathrm{nmol}$ nitrogen was added per $\mathrm{L}$ to the incubation bottles. The $\mathrm{N}: \mathrm{P}$ ratio at the start of the experiments was 0.2, 0.9, and 0.5 (Table 3) for B2-B4 respectively. After the addition of dust and dissolution of nitrogen and $\mathrm{P}$, the $\mathrm{N}: \mathrm{P}$ ratio increased in all incubations to $1.3,2.3$, and 2.3 in $\mathrm{B} 2-\mathrm{B} 4$, respectively. Although these ratios are much lower than the Redfield ratio of 16N:1P (Redfield et al., 1963), this subtle increase in the amount of nitrogen relative to phosphorus may have stimulated the rate of APA. Indeed, Ruttenburg and Dyhrman (2012) hypothesize that APA is sensitive to the N:P ratio and not just the phosphate concentration.

We found that the rate of APA was significantly higher in the subtropical Atlantic Ocean relative to the subtropical Pacific Ocean. To a first order, this is probably due to the phosphate concentration being higher in the subtropical Pacific (108 \pm $11 \mathrm{nM})$ compared to the subtropical Atlantic $(45 \pm 5 \mathrm{nM})$ in studies used in the data synthesis exercise here. However, APA rates were significantly higher in the subtropical Atlantic even over the same relatively low concentration range of phosphate $(0-50 \mathrm{nM})$, implying that factors other the phosphate concentration influenced APA. As previously mentioned, one of the most striking differences between the subtropical North Atlantic and subtropical Pacific is that the Atlantic receives almost half the global supply of atmospheric dust (Jickells et al., 2005; Mahowald et al., 2009), causing surface ocean iron concentrations to be elevated in the Atlantic relative to the Pacific Ocean. As a consequence, areal rates of nitrogen fixation are higher in the subtropical North Atlantic $\left(250 \mu \mathrm{mol} \mathrm{N} \mathrm{m}{ }^{-2} \mathrm{~d}^{-1}\right.$; Capone et al., 2005) relative to the North Pacific (30-120 $\mu \mathrm{mol} \mathrm{N} \mathrm{m} \mathrm{N}^{-2} \mathrm{~d}^{-1}$; Dore et al., 2002) and South Pacific (30-70 $\mu \mathrm{mol} \mathrm{N} \mathrm{m}{ }^{-2} \mathrm{~d}^{-1}$; Raimbault and Garcia, 2008), where nitrogen fixation is considered to be iron limited (Sohm et al., 2011). Thus, fertilization of surface waters with nitrogen via nitrogen fixation forces the system toward phosphate limitation and organisms produce AP to meet their metabolic phosphorus demands. In contrast, nitrogen fixation is lower in the iron-deplete subtropical Pacific, allowing phosphate concentrations to be relatively high, thus repressing APA (Duhamel et al., 2010, 2011). However, this narrative does not explain why AP is lower in the subtropical Pacific relative to the subtropical Atlantic Ocean even over the same phosphate concentration range. A second but more speculative argument is based on the trace metal requirement of phosphatase enzymes, specifically PhoX, which requires iron (Yong et al., 2014) and PhoA, which requires zinc (Coleman, 1992), both of which are lower in the subtropical Pacific compared to the subtropical Atlantic Ocean.

The addition of dust in bioassays stimulated the rate of APA. While the phosphorus demands of nitrogen fixers, or subtle 

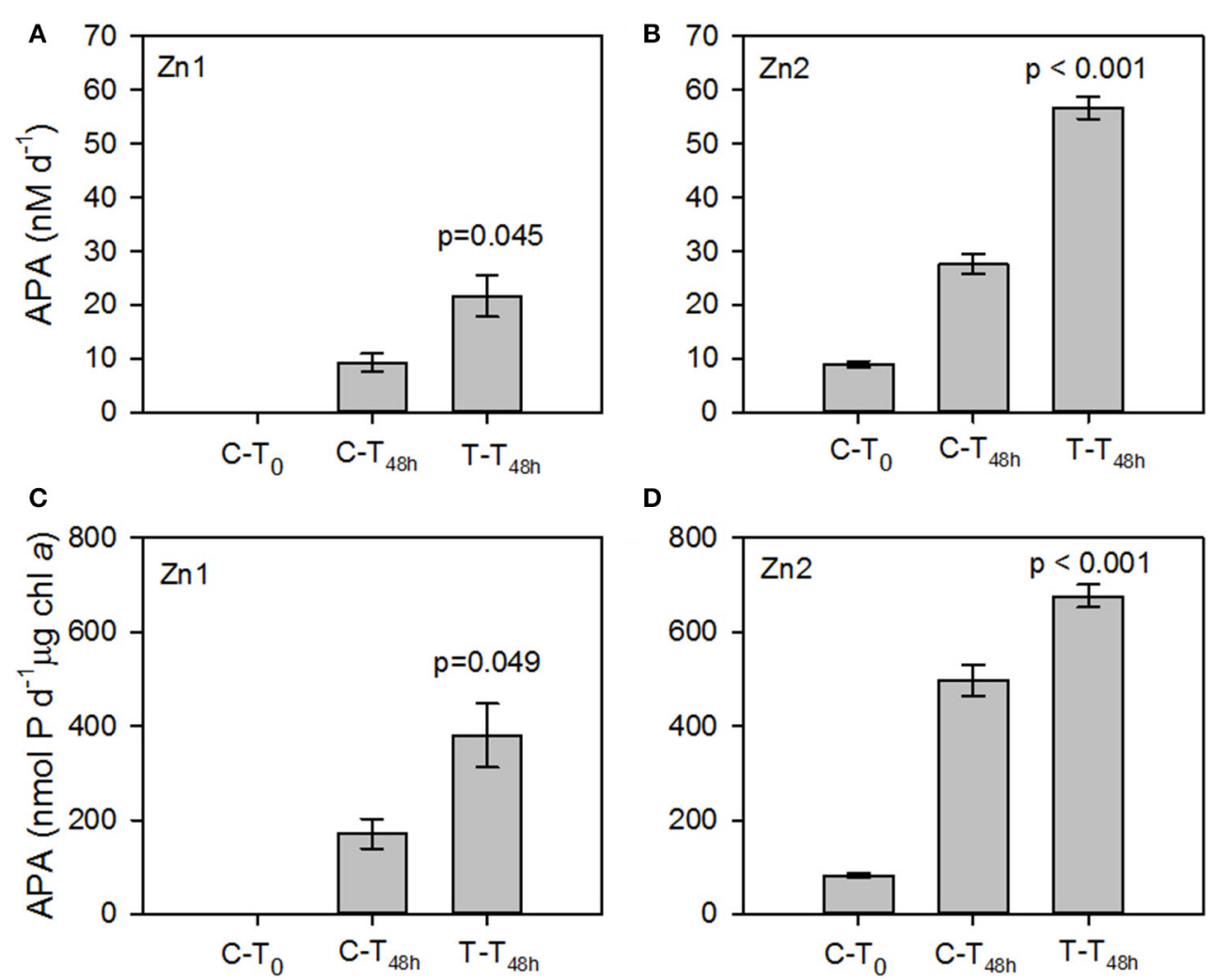

D

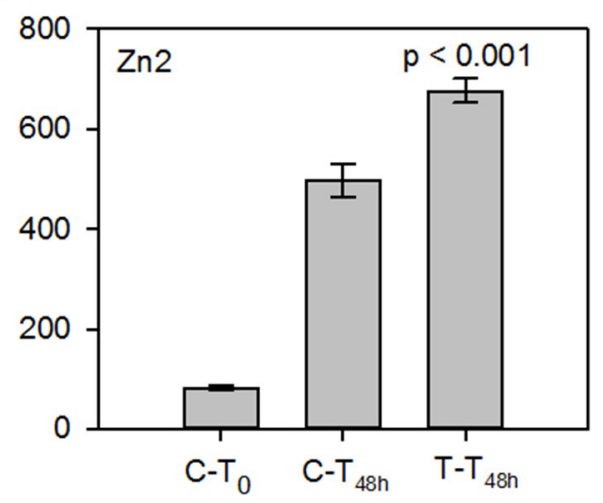

FIGURE 4 | Mean volumetric rates (nM d-1, A,B) and chlorophyll a normalized rates ( $\left.\mathrm{nmol} P \mathrm{~d}^{-1} \mu \mathrm{g} \mathrm{chl} a, C, D\right)$ of alkaline phosphatase activity (APA) in response to the addition of zinc chloride ( $\mathrm{Zn}$ ) during $(A, C) \mathrm{Zn} 1$ at $0.83^{\circ} \mathrm{N}, 25.2^{\circ} \mathrm{W}$ and $(B, D) \mathrm{Zn} 2$ at $15.9^{\circ} \mathrm{N}$ and $28.7^{\circ} \mathrm{W}$.
Error bars are \pm 1 standard error (SE). Data presented represents the initial rate of APA in the control $\left(C-T_{0}\right)$ and the rate of APA after incubation with $\mathrm{Zn}$ for $48 \mathrm{~h}$ in the Control $\left(\mathrm{C}-\mathrm{T}_{48 \mathrm{~h}}\right)$ and Treatment $\left(\mathrm{T}-\mathrm{T}_{48 \mathrm{~h}}\right)$. Values represent the $p$-value between the control and treatment at $T_{48} \mathrm{~h}$. differences in nutrient stoichiometry may have induced APA, the dissolution of iron from dust may have had a direct impact, as some AP such as PhoX, contain iron (Yong et al., 2014). However, the addition of iron alone in bioassays caused the rate of APA to decrease relative to the control rather than increase. The subtropical Atlantic is considered to be iron-replete and thus iron may not constrain the activity of PhoX in this region. However, further investigation is required to examine the relationship between iron and PhoX in the ocean (Moore, 2014).

There is ongoing debate on the potential for zinc to limit the synthesis of AP, such as PhoA, which contains at least two zinc ions in the three metal binding sites available (Coleman, 1992; Jakuba et al., 2008, 2012; Cox and Saito, 2013). We observed a significant increase in the rate of APA $48 \mathrm{~h}$ after the addition of $\sim 1.5 \mathrm{nM}$ of zinc in two experiments conducted near the equator and at $\sim 16^{\circ} \mathrm{N}$ in the eastern subtropical Atlantic. At each station, the surface ocean concentration of zinc was relatively low ( 0.16 and $0.30 \mathrm{nM}$; Table 4) and a similar significant increase in the rate of APA was observed at both stations. Our results imply that the concentration of zinc in surface waters in the subtropical Atlantic limits the activity of AP.

Previously, culture based experiments have shown the potential for zinc limitation of APA in Emiliania huxleyi (Shaked et al., 2006; Jakuba et al., 2008) and Synechococcus (Cox and Saito,
2013). In the latter study, the concentration of an APA-related protein was 5-times higher when Synechococcus was grown under phosphate deplete, zinc replete conditions compared to phosphate and zinc replete conditions (Cox and Saito, 2013). These culture-based studies have provided quantitative constraints on the zinc demand of key phytoplankton in the ocean, but evidence of zinc limitation from the subtropical ocean is sparse. On a basin scale, the regression slope between zinc and phosphate is much higher in the Atlantic (593-7870) relative to the Pacific Ocean (251-373; Jakuba et al., 2008 and references therein), implying a higher apparent uptake of zinc relative to phosphate in the Atlantic relative to the Pacific, possibly to meet the zinc demand for APA (or PhoA), thus driving the system toward zinc limitation. To our knowledge, results from this study provide the first direct evidence for limitation of APA by zinc.

\section{CONCLUSIONS}

Our data synthesis, in-situ observations and bioassay experiments demonstrates that (a) the relationship between APA and phosphate is consistent across subtropical regions, (b) the rate of APA increases significantly below a threshold phosphate concentration of $30 \mathrm{nM}$ (c) enhanced APA decreases the concentration of DOP, (d) APA is repressed by the addition of phosphate and induced 
by the addition of nitrogen, (e) the addition of dust enhances APA, (f) the rate of APA is higher in the subtropical Atlantic relative to the subtropical Pacific, possibly due to co-limitation of APA by trace metals such as iron and zinc, and (g) there is direct evidence for limitation of APA by zinc. This information should help further our basin scale understanding of phosphate cycling and limitation. However, while the patterns are consistent, the accuracy of current estimates of AP as well as our understanding of the role of phytoplankton groups may be uncertain. Using bioinformatics, a recent study found that $41 \%$ of AP is in the cytoplasm of a cell rather than the periplasm (Luo et al., 2009). A consequence of this is that current techniques used to measure APA using MUF-P may underestimate the activity as MUF-P cannot be transported across the cell membrane and therefore measures extracellular APA only (Luo et al., 2009; White, 2009). In addition, the ubiquitous cyanobacterium, Trichodemsium are known to contribute significantly to water column APA (81-90\%; Sohm et al., 2008; Orcutt et al., 2013). However, there is evidence that epibiotic bacteria living on Trichodesmium colonies use quorum sensing to regulate APA and thus influence the phosphorus available to Trichodesmium (van Mooy et al., 2012). This complicates our interpretation of AP as it is not only regulated by the extent of nutrient limitation for the broad phytoplankton community but is dependent upon microbe-host interactions.

Our understanding of AP has improved significantly over the past decade due to the increase in number of studies focused on quantifying the rate of AP and its role in the cycling of phosphorus in the ocean (Sebastián et al., 2004a,b; Sohm and Capone, 2006; Mather et al., 2008; Sohm et al., 2008; Duhamel et al., 2010, 2011; Lomas et al., 2010; Orchard et al., 2010; Suzumura et al., 2012; McLaughlin et al., 2013; Sato et al., 2013; Wurl et al., 2013; Martin et al., 2014; Reynolds et al., 2014) and the detection of genes and proteins associated with the enzyme (Orchard et al., 2009; Scanlan et al., 2009; Tetu et al., 2009; Kathuria and Martiny, 2011; Cox and Saito, 2013; Reistetter et al., 2013). However, further work is required to understand the role of trace metals, particularly zinc and iron, in regulating the rate of APA and constraining the activity of different phosphatases, such as PhoA and PhoX, which have different trace metal requirements.

\section{ACKNOWLEDGMENTS}

The authors would like to thank the Captain and Crew of the RRS Discovery, E. Achterberg for the invitation to participate in D326, M. Woodward for phosphate data, C. M. Moore for nitrogen fixation rate data, D. Purdie for chlorophyll data from bioassays conducted during D326 and P. Statham for access to unpublished data on dust dissolution experiments. This research was funded by NERC as part of the UKSOLAS program (awarded to E. Achterberg) and UK GEOTRACES program (awarded to Maeve C. Lohan, NE/G016267/1) and a standard grant (awarded to Claire Mahaffey, NE/G018782/1). We would like to acknowledge the following scientists for providing raw data from published manuscripts: C. Cutter, S. Dyhrman, S. Duhamel, M. Lomas, P. Martin, M. Sato, J. Sohm, M. Suzumura, O. Wurl, and L. Zimmer.

\section{SUPPLEMENTARY MATERIAL}

The Supplementary Material for this article can be found online at: http://www.frontiersin.org/journal/10.3389/fmars. 2014.00073/abstract

\section{REFERENCES}

Ammerman, J. W. (1993). "Microbial cycling of inorganic and organic phosphorus in the water column," in Handbook of Methods in Aquatic Microbial Ecology, eds P. F. Kemp, B. F. Sherr, E. B. Sherr, and J. J. Cole (Boca Raton, FL: Lewis Press), 621-631.

Baker, A. R., Adams, C., Bell, T. G., Jickelss, T. D., and Ganzeveld, L. (2013). Estimation of atmospheric nutrient inputs to the Atlantic Ocean from $50^{\circ} \mathrm{N}$ to $50^{\circ} \mathrm{S}$ based on large-scale field sampling: iron and other dust-associated elements. Glob. Biogeochem. Cycles 27, 755-767. doi: 10.1002/gbc20062

Bergquist, B. A., and Boyle, E. A. (2006). Dissolved iron in the tropical and subtropical Atlantic Ocean. Glob. Biogeochem. Cycles 20, GB1015. doi: 10.1029/2005GB002505

Blain, S., Bonnet, S., and Guieu, C. (2008). Dissolved iron distribution in the tropical and sub tropical South Eastern Pacific. Biogeosciences 5, 269-280. doi: 10.5194/bg-5-269-2008

Boyle, E. A., Bergquist, B. A., Kayser, R. A., and Mahowald, N. (2005). Iron, manganese and lead at Hawaii Ocean Time-series station ALOHA: temporal variability and an intermediate water hydrothermal plume. Geochim. Cosmochim. Acta 69, 933-952. doi: 10.1016/j.gca.2004.07.034

Brown, M. T., Landing, W. M., and Measures, C. I. (2005). Dissolved and particulate Fe in the western and central North Pacific: results from the 2002 IOC cruise. Geochem. Geophys. Geosyst. 6, Q10001. doi: 10.1029/2004GC00893

Capone, D. G., Burns, J. A., Montoya, J. P., Subramaniam, A., Mahaffey, C., Gunderson, T., et al. (2005). Nitrogen fixation by Trichodesmium spp.: an important source of new nitrogen to the tropical and subtropical North Atlantic Ocean. Glob. Biogeochem. Cycles 19, GB2024. doi: 10.1029/2004GB0 02331

Cavender-Bares, K. K., Karl, D. M., and Chisholm, S. W. (2001). Nutrient gradients in the western North Atlantic Ocean: relationship to microbial community structure and comparison to patterns in the Pacific Ocean. Deep Sea Res. I 48, 2373-2395. doi: 10.1016/S0967-0637(01)00027-9

Cembella, A., Antia, N. J., and Harrison, P. J. (1984a). The utilisation of inorganic and organic phosphorus compounds as nutrients by eukaryotic microalgae: a multidisciplinary perspective. Part 2, CRC Crit. Rev. Microbiol. 11, 13-81.

Cembella, A. D., Antia, N. J., and Harrison, P. J. (1984b). The utilisation of inorganic and organic phosphorus compounds as nutrients by eukaryotic microalgae: a multidisciplinary perspective. Part 1, CRC Crit. Rev. Microbiol. 10, 317-391.

Coleman, J. E. (1992). Structure and mechanism of alkaline phosphatase. Ann. Rev. Biophys. Biomol. Struct. 21, 441-483.

Cox, A. D., and Saito, M. A. (2013). Proteomic responses of oceanic Synechococcus WH8102 to phosphate and zinc scarcity and cadmium additions. Front. Microbiol. 4:387. doi: 10.3389/fmicb.2013.00387

Dore, J. E., Brum, J. R., Tupas, L. M., and Karl, D. M. (2002). Seasonal and interannual variability in sources of nitrogen supporting export in the oligotrophic subtropical North Pacific Ocean. Limnol. Oceanogr. 47, 1595-1607. doi: 10.4319/lo.2002.47.6.1595

Duhamel, S., Bjorkman, K. W., Van Wambeke, F., Moutin, T., and Karl, D. M. (2011). Characterization of alkaline phosphatase activity in the North and South Pacific subtropical gyres: implications for phosphorus cycling. Limnol. Oceanogr. 56, 1244-1254. doi: 10.4319/lo.2011.56.4.1244

Duhamel, S., Dyhrman, S. T., and Karl, D. M. (2010). Alkaline phosphatase activity and regulation in the North Pacific subtropical gyre. Limnol. Oceangr. 55, 1414-1425. doi: 10.4319/lo.2010.55.3.1414

Dyhrman, S. T., and Ruttenberg, K. C. (2006). Presence and regulation of alkaline phosphatase activity in eukaryotic phytoplankton from the coastal ocean: implications for dissolved organic phosphorus remineralisation. Limnol. Oceanogr. 51, 1381-1390. doi: 10.4319/lo.2006.51.3.1381

Dyhrman, S. T., Jenkins, B. D., Rynearson, T. A., Saito, M. A., Mercier, M. L., Alexander, H., et al. (2012). The transcriptome and proteome of the diatom Thalassiosira pseudonana reveal a diverse phosphorus stress response. PLoS ONE 7:e33768. doi: 10.1371/ journal.pone.0033768 
Dyhrman, S. T., and Palenik, B. (1999). Phosphate stress in cultures and field populations of the dinoflagellates Prorocentrum minimum detected by a single-cell alkaline phosphatase assay. Appl. Environ. Microbiol. 65, 3205-3212.

Dyhrman, S. T., and Palenik, B. P. (1997). The identification and purification of a cell-surface alkaline phosphatase from the dinoflagellate Prorocentrum minimum (Dinophyceae). J. Phycol. 33, 602-612.

Guieu, C., Loye-Pilot, M. D., Ridame, C., and Thomas, C. (2002). Chemical characterization of Saharan dust end-member: some biogeochemical implications for the western Mediterranean Sea. J. Geophys. Res. 107, 4258. doi: 10.1029/2001JD000582

Hoppe, H. G. (2003). Phosphatase activity in the sea. Hydrobiologia 493, 187-200. doi: 10.1023/A:1025453918247

Huang, B., and Hong, H. (1999). Alkaline phosphatase activity and utilization of dissolved organic phosphorus by algae in subtropical coastal waters. Mar. Pollut. Bull. 39, 205-211.

Hynes, A. M., Chappell, P. D., Dyhrman, S. T., Doney, S. C., and Webb, E. A. (2009). Cross-basin comparison of phosphorus stress and nitrogen fixation in Trichodesmium. Limnol. Oceanogr. 54, 1438-1448. doi: 10.4319/lo.2009.54.5.1438

Jakuba, R. W., Moffett, J. W., and Dyhrman, S. T. (2008). Evidence for the linked biogeochemical cycling of zinc, cobalt, and phosphorus in the western North Atlantic Ocean. Glob. Biogeochem. Cycles 22, GB4012. doi: 10.1029/2007GB003119

Jakuba, R. W., Saito, M., Moffett, J. W., and Xu, Y. (2012). Dissolved zinc in the subarctic North Pacific and Bering sea: its distribution, speciation, and importance to primary producers. Glob. Biogeochem. Cycles 26, HB2015. doi: 10.1029/2010GB004004

Jickells, T. D., An, Z. S., Andersen, K. K., Baker, A. R., Bergametti, G., Brooks, N., et al. (2005). Global iron connections between desert dust, ocean biogeochemistry, and climate. Science 308, 67-71. doi: 10.1126/science.1105959

Karl, D. M., and Björkman, K. B. (2002). "Dynamics of DOP," in Biogeochemistry of Marine Dissolved Organic Matter, eds D. Hansell and C. Carlson (New York, NY: Elsevier), 249-366.

Karl, D. M., and Yanagi, K. (1997). Partial characterization of the dissolved organic phosphorus pool in the oligotrophic North Pacific Ocean. Limnol. Oceanogr. 42, 1398-1405.

Kathuria, S. K., and Martiny, A. C. (2011). Prevalence of a calcium-based alkaline phosphatase associated with the marine cyanobacterium Prochlorococcus and other ocean bacteria. Environ. Microbiol. 13, 74-83. doi: 10.1111/j.14622920.2010.02310.x

Kolowith, L. C., Ingall, E. D., and Benner, R. (2001). Composition and cycling of marine organic phosphorus. Limnol. Oceanogr. 46, 309-320. doi: 10.4319/lo.2001.46.2.0309

Langlois, R. J., Mills, M. M., Ridame, C., Croot, P., and LaRoche, J. (2012). Diazotrophic bacteria respond to Saharan dust additions. Mar. Ecol. Prog. Ser. 470, 1-14. doi: 10.3354/meps 10109

Lin, H.-Y., Shih, C.-H., Liu, H.-C., Chang, J., Chen, Y.-L., Chen, Y.-R., et al. (2013). Extracellular Alkaline Phosphatase in the marine diatom Phaeodactylum tricornutum. J. Mar. Biotech. 15, 425-436. doi: 10.1007/s10126-013-9494-3

Lin, X., Zhang, H., Cui, Y., and Lin, S. (2012). High sequence variability, diverse subcellular localizations, and ecological implications of alkaline phosphatase in dinoflagellates and other eukaryotic phytoplankton. Front. Microbiol. 3:235. doi: 10.3389/fmicb.2012.00235

Lomas, M. W., Burke, A. L., Lomas, D. A., Bell, D. W., Shen, C., Dyhrman, S. T., et al. (2010), Sargasso Sea phosphorus biogeochemistry: an important role for dissolved organic phosphorus (DOP). Biogeosciences 7, 695-710. doi: 10.5194/bg-7-695-2010

Luo, H., Benner, R., Long, R. A., and Hu, J. (2009). Subcellular localization of marine bacterial alkaline phosphatases. Proc. Natl. Acad. Sci. U.S.A. 106, 21219-21223. doi: 10.1073/pnas.0907586106

Luo, H., Zhang, H., Long, R. A., and Benner, R. (2011). Depth distributions of alkaline phosphatase and phosphonate utiliation genes in the North Pacific subtropical gyre. Aquat. Microbiol. Ecol. 62, 61-69. doi: 10.3354/ame01458

Mahowald, N. M., Engelstaedter, S., Luo, C., Sealy, A., Atraxo, P., BenitezNelson, C., et al. (2009). Atmospheric iron deposition: global distribution, variability and human perturbations. Ann. Rev. Mar. Sci. 1, 245-278. doi: 10.1146/annurev.marine.010908.163727

Martin, P., Dyhrman, S. T., Lomas, M. W., Poulton, N. J., and van Mooy, B. A. S. (2014). Accumulation and enhanced cycling of polyphosphate by Sargasso
Sea plankton in response to low phosphorus. Proc. Natl. Acad. Sci. U.S.A. 111, 8089-8094. doi: 10.1073/pnas.1321719111

Mather, R. L., Reynolds, S. E., Wolff, G. A., Williams, R. G., Torres-Valdes, S., Pan, X., et al. (2008). Contrasting phosphorus cycling in Atlantic Ocean deserts. Nat. Geosci. 1, 439-443. doi: 10.1038/ngeo232

McLaughlin, K., Sohm, J. A., Cutter, G. A., Lomas, M. W., and Paytan, A. (2013). Phosphorus cycling in the Sargasso Sea: investigation using the oxygen isotopic composition of phosphate, enzyme-labeled fluorescence, and turnover times. Glob. Biogeochem. Cycles 27, 1-13. doi: 10.1002/gbc.20037

Mills, M. M., Ridame, C., Davey, M., LaRoche, J., and Geider, R. J. (2004). Iron and phosphorus co-limit nitrogen fixation in the eastern tropical North Atlantic. Nature 429, 292-432. doi: 10.1038/nature02550

Moore, C. M. (2014). Microbial proteins and oceanic nutrient cycles. Science 345, 1120. doi: $10.1126 /$ science. 1258133

Moore, C. M., Mills, M., Achterberg, E. P., Geider, R. J., La Roche, J., Lucas, M. I., et al. (2009). Large-scale distribution of Atlantic nitrogen fixation controlled by iron availability Nat. Geosci. 2, 867-871. doi: 10.1038/ngeo667

Moore, C. M., Mills, M., Langlois, R. J., Milne, A., Achterberg, E. P., La Roche, J., et al. (2008). Relative influence of nitrogen and phosphorous availability on phytoplankton physiology and productivity in the oligotrophic sub-tropical North Atlantic Ocean. Limnol. Oceanogr. 53, 291-305. doi: 10.4319/lo.2008.53. 1.0291

Moore, C. M., Mills, M. M., Milne, A., Langlois, A., Achterberg, E. P., Lochte, K., et al. (2006). Iron limits primary productivity during spring bloom development in the central North Atlantic. Glob. Change Biol. 12, 626-634. doi: 10.1111/j.1365-2486.2006.01122.x

Nausch, M., and Nausch, G. (2004). Bacterial utilisation of phosphorus pools after nitrogen and carbon amendment and its relation to alkaline phosphatase activity. Aquat. Microbiol. Ecol. 37, 237-245. doi: 10.3354/ame037237

Neddermann, K., and Nausch, M. (2004). Effects of organic and inorganic nitrogen compounds on the activity of bacterial alkaline phosphatase. Aquat. Ecol. 38, 475-484. doi: 10.1007/s10452-004-5666-6

Orchard, E. D., Ammerman, J. W., Lomas, M. W., and Dyhrman, S. T. (2010). Dissolved inorganic and organic phosphorus uptake in Trichodesmium and the microbial community: the importance of phosphorus ester in the Sargasso Sea. Limnol. Oceanogr. 55, 1390-1399. doi: 10.4319/lo.2010.55.3.1390

Orchard, E. D., Webb, E. A., and Dyhrman, S. T. (2009). Molecular analysis of the phosphorus starvation response in Trichodesmium spp. Environ. Microbiol. 11, 2400-2411. doi: 10.1111/j.1462-2920.2009.01968.x

Orcutt, K. M., Gundersen, K., and Ammerman, J. W. (2013). Intense ectoenzyme activities associated with Trichodesmium colonies in the Sargasso Sea. Mar. Ecol. Progr. Ser. 478, 101-113. doi: 10.3354/meps10153

Patey, M. D., Rijkenberg, M. J. A., Statham, P. J., Stinchcombe, M. C., Achterberg, E. P., and Mowlem, M. (2008). Determination of nitrate and phosphate in seawater at nanomolar concentrations. TrAC Trends Anal. Chem. 27, 169-182. doi: 10.1016/j.trac.2007.12.006

Perry, M. J. (1972). Alkaline phosphatase activity in subtropical central North Pacific waters using a sensitive fluorometric method. Mar. Biol. 15, 113-119.

Raimbault, P., and Garcia, N. (2008). Evidence for efficient regenerated production and dinitrogen fixation in the nitrogen-deficient waters of the South Pacific Ocean: impact of new and export production estimates. Biogeosciences 5, 323-338. doi: 10.5194/bg-5-323-2008

Redfield, A. C., Ketchum, B. H., and Richards, F. A. (1963). "The influence of organisms on the composition of sea-water," in The Sea. Ideas and Observations on Progress in the Study of the Seas, Vol. 2. The Composition of Sea-Water. Comparative and Descriptive Oceanography, ed M. M. Hill (New York, NY: Interscience Publishers, John Wiley \& Sons), 26-77.

Reistetter, E. N., Krumhardt, K., Callnan, K., Roache-Johnson, J., Saunders, J. K., Moore, L. R., et al. (2013). Effects of phosphorus starvation versus limitation on the marine cyanobacterium Prochlorococcus MED4 II: gene expression. Environ. Microbiol. 15, 2129-2143. doi: 10.1111/1462-2920.12129

Reynolds, S., Mahaffey, C., Roussenov, V., and Williams, R. G. (2014). Evidence for production and lateral transport of dissolved organic phosphorus in the eastern subtropical North Atlantic. Glob. Biogeochem. Cycle 28, 805-824. doi: 10.1002/ 2013GB004801

Rijkenberg, M. J. A., Powell, C. F., Dall'Osto, M., Nielsdottir, M. C., Patey, M. D., Hill, P. G., et al. (2008). Changes in iron speciation following a Saharan dust event in the tropical North Atlantic Ocean. Mar. Chem. 110, 56-67. doi: 10.1016/j.marchem.2008.02.006 
Rijkenberg, M. J. A., Steigenberger, S., Powell, C. F., van Haren, H., Patey, M. D., Baker, A. R., et al. (2012). Fluxes and distribution of dissolved iron in the eastern (sub-) tropical North Atlantic Ocean, Glob. Biogeochem. Cycles 26, GB3004. doi: 10.1029/2011GB004264

Ruttenburg, K. C., and Dyhrman, S. T. (2012). Dissolved organic phosphorus production during simulated phytoplankton blooms in a coastal upwelling system. Front. Microbiol. 3:274. doi: 10.3389/fmicb.2012. 00274

Sarthou, G., Baker, A. R., Blain, S., Achterberg, E. P., Boye, M., Bowie, A. R., et al. (2003). Atmospheric iron deposition and sea surface dissolved iron concentrations in the eastern Atlantic Ocean. Deep Sea Res. I 50, 1339-1352. doi: 10.1016/S0967-0637(03)00126-2

Sato, M., Sakuraba, R., and Hashihama, F. (2013). Phosphate monoesterase and diesterase activities in the North and South Pacific Ocean. Biogeosciences 10, 7677-7688. doi: 10.5194/bg-10-7677-2013

Scanlan, D. J., Ostrowski, M., Mazard, S., Dufresne, A., Garczarek, L., Hess, W. R., et al. (2009). Ecological genomics of marine picocyanobacteria. Microbiol. Mol. Biol. Rev. 73, 249-299. doi: 10.1128/MMBR.00035-08

Schlosser, C., Klar, J. K., Wake, B. D., Snow, J. T., Honey, D. J., Woodward, E. M. S., et al. (2014). Seasonal ITCZ migration dynamically controls the location of the (sub) tropical Atlantic biogeochemical divide. Proc. Natl. Acad. Sci. U.S.A. 111, 1438-1442. doi: 10.1073/pnas.1318670111

Sebastián, M., Aristegui, J., Montero, M. F., Escanez, J., and Niell, F. X. (2004b). Alkaline phosphatase activity and its relationship to inorganic phosphorus in the transition zone of the North-western African upwelling system. Prog. Oceangr. 62, 131-150. doi: 10.1016/j.pocean.2004.07.007

Sebastián, M., Arístegui, J., Montero, M. F., and Niell, F. X. (2004a). Kinetics of alkaline phosphatase activity, and effect of phosphate enrichment: a case study in the NW African upwelling region. Mar. Ecol. Prog. Ser. 270, 1-13. doi: 10.3354/meps270001

Shaked, Y., Xu, Y., Leblanc, K., and Morel, F. M. M. (2006). Zinc availability and alkaline phosphatase activity in Emiliania huxleyi: implications for $\mathrm{Zn}-\mathrm{P}$ co-limitation in the ocean. Limnol. Oceanogr. 51, 299-309. doi: 10.4319/lo.2006.51.1.0299

Sohm, J. A., and Capone, D. G. (2006). Phosphorus dynamics of the tropical and subtropical north Atlantic: Trichodesmium spp. versus bulk plankton. Mar. Ecol. Progr. Ser. 317, 21-28. doi: 10.3354/meps317021

Sohm, J. A., Mahaffey, C., and Capone, D. G. (2008). Assessment of relative phosphorus limitation of Trichodesmium spp. in the North Pacific and Atlantic and the North Coast of Australia. Limnol. Oceanogr 53, 2495-2502. doi: 10.4319/lo.2008.53.6.2495

Sohm, J. A., Webb, E. A., and Capone, D. G. (2011). Emerging patterns of marine nitrogen fixation. Nat. Rev. 9, 499-508. doi: 10.1038/nrmicro2594

Suzumura, M., Hashihama, F., Yamada, N., and Kinouchi, S. (2012). Dissolved phosphorus pools and alkaline phosphatase activity in the euphotic zone of the western North Pacific Ocean. Front. Microbiol. 3:99. doi: 10.3389/fmicb.2012. 00099

Tetu, S. G., Brahamsha, B., Johnson, D. A., Tai, V., Phillippy, K., Palenik, B., et al. (2009). Microarray analysis of phosphate regulation in the marine cyanobacterium, Synechococcus sp. WH8102. ISME J. 3, 835-849. doi: 10.1038/ismej.2009.31
Ussher, S. J., Achterberg, E. P., Powell, C., Baker, A. R., Jickells, T. D., Torres, R., et al. (2013). Impact of atmospheric deposition on the contrasting iron biogeochemistry of the North and South Atlantic Ocean. Glob. Biogeochem. Cycles 27, 1096-1107. doi: 10.1002/gbc.20056

van Mooy, B. A. S., Hmelo, L. R., Sofen, L. E., Campagna, S. R., May, A. L., Dyhrman, S. T., et al. (2012). Quorum sensing control of phosphorus acquisition in Trichodesmium consortia. ISME J. 6, 422-429. doi: 10.1038/ismej.2011.115

Wanner, B. L. (1996). "Phosphorus assimilation and control of the phosphate regulon," in Escherichia coli and Samonella: Cellular and Molecular Biology, ed F. C. Neidhardt (Washington, DC: American Society of Microbiology), 1357-1381.

White, A. (2009). New insights into the bacterial acquisition of phosphorus in the surface ocean. Proc. Natl. Acad. Sci. U.S.A. 106, 21013-21014. doi: 10.1073/pnas.0912475107

Williams, R. G., McDonagh, E., Roussenov, V. M., Torres-Valdes, S., King, B., Sanders, R., et al. (2011). Nutrient streams in the North Atlantic: advective pathways of inorganic and organic nutrients. Glob. Biogeochem. Cycles 25, GB4008. doi: 10.1029/2010GB003853

Wu, J., Sunda, W., Boyle, E. A., and Karl, D. M. (2000). Phosphate depletion in the western North Atlantic Ocean. Science 289, 759-762. doi: 10.1126/science.289. 5480.759

Wurl, O., Zimmer, L., and Cutter, G. A. (2013). Arsenic and phosphorus biogeochemistry in the ocean. arsenic species as proxies for P-limitation. Limnol. Oceanogr. 58, 729-740. doi: 10.4319/lo.2013.58.2.0729

Wyatt, N. J., Milne, A., Woodward, E. M. S., Rees, A. P., Browning, T. J., Bouman, H. A., et al. (2014). Biogeochemical cycling of dissolved zinc along the GEOTRACES South Atlantic transect GA10 at $40^{\circ}$ S. Glob. Biogeochem. Cycles 28, 44-56. doi: 10.1002/2013GB004637

Xylouri, A. (2009). Impact of Atmospheric Cycling on Release of Iron and Manganese into Seawater from Saharan Soil Particles. Ph.D. thesis, University of Leeds.

Yong, S. C., Roversi, P., Lillington, J., Rodriguez, F., Krehenbrink, M., et al. (2014). A complex iron-calcium cofactor catalyzing phosphotransfer chemistry. Science 345, 1170. doi: 10.1126/science. 125423

Conflict of Interest Statement: The authors declare that the research was conducted in the absence of any commercial or financial relationships that could be construed as a potential conflict of interest.

Received: 16 October 2014; accepted: 20 November 2014; published online: 16 December 2014.

Citation: Mahaffey C, Reynolds S, Davis CE and Lohan MC (2014) Alkaline phosphatase activity in the subtropical ocean: insights from nutrient, dust and trace metal addition experiments. Front. Mar. Sci. 1:73. doi: 10.3389/fmars.2014.00073

This article was submitted to Marine Biogeochemistry, a section of the journal Frontiers in Marine Science.

Copyright (C) 2014 Mahaffey, Reynolds, Davis and Lohan. This is an open-access article distributed under the terms of the Creative Commons Attribution License (CC BY). The use, distribution or reproduction in other forums is permitted, provided the original author(s) or licensor are credited and that the original publication in this journal is cited, in accordance with accepted academic practice. No use, distribution or reproduction is permitted which does not comply with these terms. 